\section{読者の広場 4}

\section{FT-IR・ラマン分光法講習会の報告}

日本分光学会主催の FT-IR · ラマン 分光法講習会が 昨年（昭和63年）12月 5 日から 7 日の三日間に亘って開 かれました.この講習会は毎年行われて来た赤外 FT-IR 分光の講習会の内容にラマン分光法を加えたものでし た. 講義はラマン分光に重点を掻いた内容でしたが，実 習は FT-IR，ラマン両方について行いました. 受講者 は各企業, 大学でこの分野の研究, 材料の分析, 評価に 従事している人達や，またこの分野にこれから進出して 行こうとしている人達で，定員一杯（70名）でした.

最近ラマン，赤外分光法の応用の範用は非常に広くな って扣り，この講習会の企画で総ての分野をカバーしょ らとすることはなかなか難しいことでした. 講義で取り 上げられたトピックスは半導体，高温超伝導体，誘電 体，セラミックス，生体高分子，有機伝導体，有機薄膜 など多岐に亘るものでした.

講習会では第一日目に, 化学の立場からラマン散乱测 定から何が分かるのか，ラマン分光の現況はどのように なっているかと言うことが，原田（東北大）によって述 ベられました，次に結晶のラマン散乱についての原理， 装置, 散乱の効率などについて潮田（東北大）が講義を しました. 続いてシリコンを中心にした半導体の評価に 関したトピックスが中島（阪大）によって，化合物半導 体の評価に関して，種々の実験例が河東田（東大）によ って紹介されました，最近注目を集めている高温超伝導 体についてもラマン散乱は有力な解析手法と考えられて いますが，物理，化学の立場からそれぞれ水貝(阪大), 森岡（東北大）によって最近の成果が紹介されました. さらに強誘電体の相転移, それに伴らソフトモードにつ いて富永（招茶大）から解説がされました，有機伝導体 ではラマン散乱からその構造, 電荷移動量, 配向, ドー パントについて情報が得られることが古川（東大）によ って述べられました. セラミックス，ガラス，粉体など のラマン・赤外分光による 評価の例が 水野（豊田中研） によって紹介されました.

三日目は生体物質 (DNA， へム蛋白，核酸など) につ いての構造解析の一連の研究の結果が西村（東大）によ って述べられました. 種々の薄膜（高分子，グラファイ ト，表面構造物）などの評価の例が石田（東レリサーテ） によって紹介されました．金属表面の吸着種や単分子膜
を感度良く測る方法が色々と提案されていますが大沢 （東北大）惊感度反射法，ATR などの方法について解 説を行ないました. 講義の締めくくりとして赤外・ラマ ン分光の現況と将来の展望が浜口（東大）によって述べ られました．赤外・ラマン分光の仕事にたずさわる者に とって，最近開発されている顕微赤外・ラマン，時間分 解赤外・ラマン, 共鳴ラマン散乱などの手法は強力な武 器になると思われます。

近年のラマン分光器の改良, 高感度のマルチチャネル 検出器の開発, さらにラマン顕微鏡システムの開発によ ってラマン分光の分野では大きな変動（発展と言った方 が良いかも知れません）が起こると予想されます，今ま で不可能に近いと考兄られていたミクロな材料や超薄膜 の測定, 微弱ラマン光の測定が苦学することなしに出来 るのもそれ䄈ど遠くはないでしょう，熱の入った講師の 話に皆熱心に 聞き入っていましたが（写真 1 ），専門的 な話しは初心者にとっては難しかったと言う感想もあり ました。

二日目の午後から FT-IR とラマン散乱測定の実習が

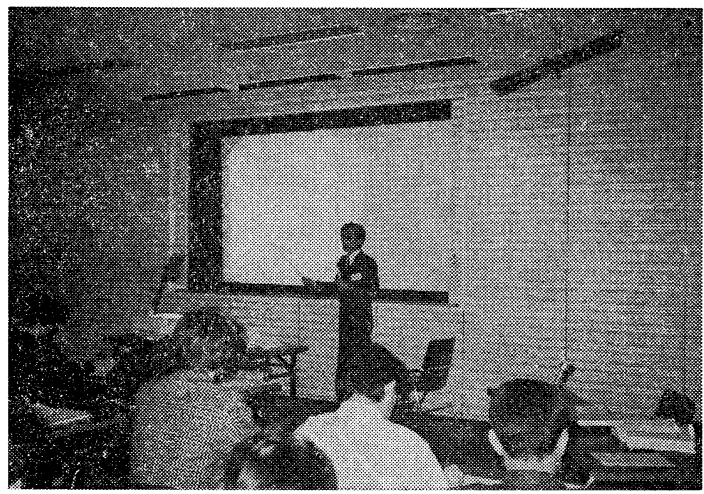

写真 1 講義に熱心に聞き入る参加者

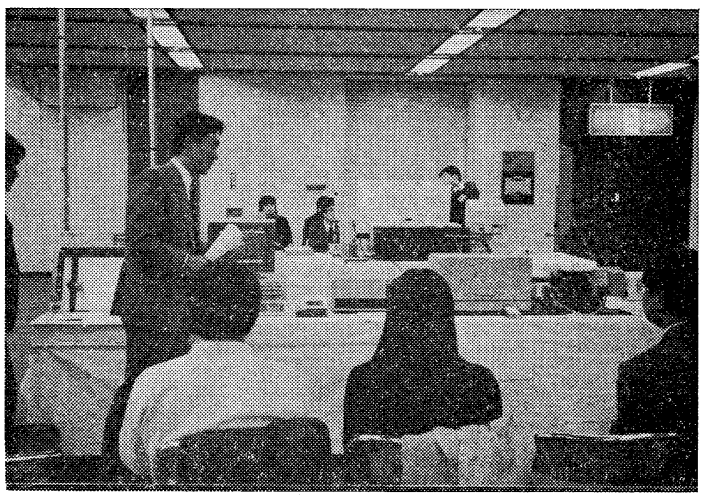

写真 2 実習会場の風景 
行われました (写真 2$).$ 多くのメーカーや代理店のご 協力を得て代表的な分光器が会場に並べられました．こ れら分光器の大きな特徴はコンピューターを使った制 御, 計測が可能で自動化されていることや，顕微鏡を備 えていてミクロ測定が可能になっていることでした.

時間の関係で全部の分光器で実習することが出来ず, 目当ての装置が割り当ててもらえなかって残念だったと の声も聞かれましたが，色々な機種が一箇所隹められ て比較できたことは有意義だったのではないかと思いま す.こんな分光器が自分の研究室にあったらなあと言う
つぶやきも聞かれましたが，あまりにも自動化されてい てなにか変わった測定をするのには不便だと感じたのは 古い世代の思い過ごしでしょらか.

最後にパネルディスカッションが開かれ講師と参加者 の間で熱心な質疑応答が交わされて終わりました.

終わりになりますが, FT-IR, ラマン分光器を講習会 に出して頂き, 実習に御協力頂いた各機器メ一カー, 代 理店の方々並びにこの講習会の企画運営, 会場の準備運 営にたずさわって来られた多くの方々に感謝致します。

(大阪大学工学部 中島信一) 